Vegetalika. 2019. 8(4): 276-291

\title{
Perbandingan Perakaran Beberapa Kultivar Kedelai (Glycine max L.) yang Mengalami Kekeringan dengan Metode Pengamatan Berbeda
}

\section{Root Comparison of Five Soybean Cultivars (Glycine max L.) in Drought Condition with Different Measurement Methods}

\author{
Yudha Pratiwi, Dody Kastono*), Didik Indradewa \\ Departemen Budidaya Pertanian, Fakultas Pertanian, Universitas Gadjah Mada \\ *) Penulis untuk koresponden Email: dodykastono@gmail.com
}

\begin{abstract}
Research on "Root comparison of five soybean cultivars (Glycine max L.) in drought condition with different measurement methods" was conducted from March-August 2018, in plastic screen house at Gadjah Mada University (UGM) Agriculture Faculty Tridarma Field, in Banguntapan and crop growth analysis was conducted at Crop Science and Crop Ecology Sub Laboratory of Crop Management Laboratory. This research's objective was to determine root characteristic in different conditions (enough water and drought) and to compare the results of root measurement with different methods (manual and area meter). The experimental was design by split plot factorial two factors with three repetitions. Two factors tested were drought treatment as the first factor and cultivar as the second factor. Drought treatment consist of two level, they were enough water treatment (be watered once a day) and drought (be watered once every 3 days). Five cultivars that used were Anjasmoro, Burangrang, Demas 1, Dering 1, and Devon 1. Analysis of variance (ANOVA) was used to analyze the data, if significantly different then proceeded to Tukey's Honest Significant Difference Test $5 \%$ to determine comparison between treatments. In this research method known that root characteritic had decreased significantly under drought condition. Root measurement both manual and areameter method can be used but the result shown that both methods gave different result of root length, root volume, and root diameter, but gave equally accurate result of root surface area.
\end{abstract}

Keywords: root, area meter, drought, manual

\section{INTISAR I}

Penelitian mengenai "Perbandingan hasil pengukuran perakaran lima kultivar kedelai (Glycine max L.) dengan metode berbeda" dilakukan di rumah plastik di Kebun Tridharma Banguntapan, Fakultas Pertanian, Universitas Gadjah Mada, Yogyakarta, sedangkan analisis pertumbuhan tanaman dilakukan di Laboratorium Manajemen Produksi Tanaman Sub Laboratorium IImu Tanaman dan Ekologi Tanaman, Fakultas Pertanian, Universitas Gadjah Mada, Yogyakarta. Penelitian berlangsung dari bulan Maret-Agustus 2018. Penelitian dilakukan dengan tujuan mempelajari sifat perakaran pada kondisi berbeda (cukup air dan kekeringan) dan membandingkan hasil pengukuran parameter perakaran dengan metode berbeda (manual dan area meter). Rancangan lingkungan yang dipakai 
berupa split plot dengan dua faktor yang diuji coba yaitu perlakuan kekeringan sebagai faktor pertama dan kultivar sebagai faktor kedua. Perlakuan kekeringan terdiri dari 2 aras yaitu cukup air dengan disiram 1 hari sekali dan kekeringan dengan disiram 3 hari sekali. Kultivar yang digunakan terdiri dari 5 macam kultivar kedelai, yaitu kultivar Anjasmoro, Burangrang, Demas 1, Dering 1, dan Devon 1. Data yang diperoleh kemudian dilakukan analisis varians (ANNOVA) dan apabila terdapat beda nyata, dilakukan uji lanjut Honest Significant Difference (Beda Nyata Jujur) Tukey $5 \%$. Pada metode penelitian ini sifat perakaran dalam kondisi kekeringan cenderung mengalami penurunan yang signifikan. Pengukuran perakaran kedelai dengan metode berbeda menunjukkan bahwa pengukuran secara manual memberikan nilai panjang akar total, volume akar, dan luas permukaan akar yang lebih besar.

Kata kunci: akar, area meter, kekeringan, manual

\section{PENDAHULUAN}

Produksi kedelai yang menurun menjadi kendala dalam memenuhi kebutuhan kedelai nasional. Produksi kedelai nasional dapat ditingkatkan dengan perluasan areal tanam melalui pemanfaatan lahan marjinal berupa lahan kering. Kendala dari lahan kering yaitu terjadinya penurunan hasil tanaman kedelai akibat dari cekaman kekeringan karena rendahnya ketersediaan air pada lahan kering. Penurunan hasil panen akan mempengaruhi produktivitas dari kedelai. Air yang terbatas mengakibatkan perkembangan akar terbatas sehingga penyerapan unsur hara oleh akar terganggu, maka perlu penggunaan kultivar kedelai yang mampu berproduksi dan tahan terhadap cekaman kekeringan.

Sistem perakaran pada tanaman kedelai dapat menentukan sifat ketahanan dan respon tanaman tersebut terhadap kondisi lingkungan yang buruk yaitu kekeringan. Tanaman kedelai yang mampu beradaptasi pada kondisi tercekam kekeringan memiliki sifat perakaran yang baik, lebat, dan dalam. Sistem perakaran yang lebat sangat penting ketika tanaman tumbuh pada kondisi air yang terbatas (Manavalan et al. 2009; Gewin, 2010). Pengamatan sistem perakaran kedelai menjadi indikator penting karena morfologi akar yang baik mampu memaksimalkan penyerapan air untuk memenuhi kebutuhan tanaman, sehingga pengamatan perakaran kedelai perlu dilakukan dengan metode yang tepat sehingga diperoleh hasil pengukuran perakaran yang lebih baik. Pada penelitian ini akan mempelajari sifat perakaran yang berada dalam kondisi berbeda yaitu cukup air dan sekeringan, serta membandingkan hasil pengukuran perakaran kedelai dengan metode berbeda yaitu secara manual dan dengan menggunakan area meter. 


\section{BAHAN DAN METODE PENELITIAN}

Penelitian dilaksanakan pada bulan Maret-Agustus 2018 di Kebun Tridharma Fakultas Pertanian, Universitas Gadjah Mada di Banguntapan, Bantul, Yogyakarta dan analisis pertumbuhan tanaman dilakukan di Laboratorium Manajemen Produksi Tanaman Sub Laboratorium IImu Tanaman dan Ekologi Tanaman, Fakultas Pertanian, Universitas Gadjah Mada. Alat yang digunakan pada penelitian ini antara lain keranjang plastik (bakul nasi) diameter $20 \mathrm{~cm}$, tali tambang, oven, timbangan analitik, alat tulis, hand counter, sprayer, gelas ukur, dan label. Bahan yang diperlukan antara lain benih lima kultivar kedelai yang diperoleh dari Balitkabi (Anjasmoro, Burangrang, Demas 1, Dering 1, dan Devon 1), pupuk Urea, pupuk KCl, pupuk SP36, media tanah, inokulan (Legin), Furadan 3G, dan Dithane M-45. Rancangan lingkungan berupa split plot dengan dua faktor yang diuji coba yaitu perlakuan kekeringan sebagai faktor pertama dan kultivar sebagai faktor kedua. Perlakuan kekeringan terdiri dari 2 aras yaitu cukup air dengan disiram 1 hari sekali dan kekeringan dengan disiram 3 hari sekali. Kultivar yang digunakan terdiri dari 5 macam kultivar kedelai.

Penanaman benih dilakukan pada keranjang plastik yang digantung dengan tali pada kerangka yang telah disiapkan di dalam rumah plastik untuk memudahkan pengamatan akar. Pengamatan dilakukan pada 5 dan $9 \mathrm{mst}$, serta panen. Variabel yang diamati antara lain panjang akar, volume akar, luas permukaan akar, dan diameter akar yang diukur secara manual dan dengan menggunakan area meter. Analisis data dilakukan menggunakan uji Annova dan uji lanjut Honest Significant Difference (Beda Nyata Jujur) Tukey $5 \%$. Panjang akar manual diukur dengan menyebar akar di atas plastik plastik mika yang telah dibuat garis kotak-kotak dengan ukuran tertentu dan dihitung perpotongan antara akar dan garis, lalu dimasukan ke dalam rumus (Yoshida, 1981):

$$
\mathrm{R}=\frac{\pi N A}{2 \mathrm{H}}
$$

Keterangan:

$\mathrm{R}=$ total length of root

$\mathrm{N}=$ number of intersection between the root and straight line

$\mathrm{A}=$ area of the rectangle

$\mathrm{H}=$ total length of the straight line

$\pi=3,14$

Pengamatan luas permukaan dan diameter akar dengan area meter dihitung dengan rumus: 


\section{Luas permukaan $=\mathrm{p} \times 2 \mathrm{r} \times \pi ;$ Diameter $=2 \times \mathrm{r}$}

Keterangan:

$\mathrm{p}=$ panjang akar area meter

$r=\sqrt{\left(\frac{\text { volumeakar }}{\pi \times P}\right)}$

$\pi \quad=3,14$

Pengamatan luas permukaan dan diameter akar dengan cara manual dihitung dengan rumus:

\section{Luas permukaan $=p \times 2 r \times \pi$; Diameter $=2 \times r$}

Keterangan:

$\mathrm{p}=$ panjang akar manual

$r \quad=\sqrt{\left(\frac{\text { volumeakar }}{\pi \times \mathrm{p}}\right)}$

$\pi \quad=3,14$

Penelitan dilaksanakan di Kebun Tridharma Fakultas Pertanian, Universitas Gadjah Mada di Banguntapan, Bantul, Yogyakarta pada bulan April-Agustus 2018. Penelitian disusun menggunakan rancangan petak terbagi (split plot). Perlakuan kekeringan yang terdiri dari 2 aras yaitu cukup air (tidak tercekam) dengan disiram 1 hari sekali dan kekeringan (tercekam) dengan disiram 7 hari sekali bertindak sebagai pihak utama dan kultivar kedelai yang terdiri dari lima kultivar yaitu Anjasmoro, Burangrang, Demas 1, Dering 1, dan Devon 1 bertindak sebagai anak petak.

Penelitian dilakukan dengan penanaman benih pada polybag di lahan yang ternaungi dalam rumah plastik. Setiap unit percobaan terdiri dari 9 polibag dikali 5 perlakuan dan 6 blok sehingga total terdapat 270 polibag. Pengambilan sampel destruktif dilakukan sebanyak tiga kali, yaitu pada 4 minggu setelah tanam (MST), 8 MST dan saat panen, maing-masing sampel diambil 2 polibag/unit percobaan. Variabel yang diamati adalah kadar lengas tanah, jumlah akar, bobot kering akar, panjang akar, luas permukaan akar, diameter akar dan indeks toleransi cekaman berdasarkan berat kering tanaman. Analisis data menggunakan ANOVA dan apabila tidak terdapat interaksi antara kedua faktor dilakukan uji Honest Significant Difference Tukey dengan taraf kepercayaan 95 \%.

Pengukuran kadar lengas dilakukan dua kali, yaitu saat sebelum penyiraman dan setelah penyiraman pada masing-masing waktu pengambilan sampel destruktif. Kadar lengas tanah diukur menggunakan rumus: 


$$
\text { Kadar Lengas }(\mathrm{KL})=\frac{B B-B K}{B K} \times 100 \%
$$

Keterangan:

$\mathrm{BK}=$ bobot kering oven

$\mathrm{BB}=$ bobot basah

Indeks toleransi cekaman (ITC) berdasarkan bobot kering tanaman dihitung menggunakan persamaan Fernandez (1992):

$$
\text { ITC Berat Kering Tanaman }=\frac{Y s Y p}{Y p^{2}}
$$

Keterangan:

Ys = Hasil biji dalam kondisi cekaman

Yp = Hasil biji dalam kondisi tidak tercekam

$\bar{Y} p^{2}=$ Rata-rata hasil biji dalam kondisi tidak tercekam

\section{HASIL DAN PEMBAHASAN}

Adapun hasil pengukuran panjang akar total dengan metode manual yang telah dilakukan dapat ditunjukkan ada Tabel 1 .

Tabel 1. Panjang akar total manual pada 5 dan $9 \mathrm{mst}$

\begin{tabular}{lcc} 
& \multirow{2}{*}{ Kultivar } & \multicolumn{2}{c}{ Panjang Akar Total Manual $(\mathrm{m})$} \\
\cline { 2 - 3 } & $5 \mathrm{mst}$ & $9 \mathrm{mst}$ \\
\hline Anjasmoro & $19.60 \mathrm{a}$ & $38.68 \mathrm{a}$ \\
Burangrang & $22.53 \mathrm{a}$ & $40.43 \mathrm{a}$ \\
Demas 1 & $22.94 \mathrm{a}$ & $37.84 \mathrm{a}$ \\
Dering 1 & $15.46 \mathrm{a}$ & $30.75 \mathrm{a}$ \\
Devon 1 & $16.82 \mathrm{a}$ & $38.42 \mathrm{a}$ \\
\hline Cukup Air & $21.28 \mathrm{y}$ & $45.49 \mathrm{y}$ \\
Kekeringan & $17.66 \mathrm{y}$ & $28.96 \mathrm{z}$ \\
\hline Interaksi & - & - \\
\hline CV(\%) & 26.36 & 14.97 \\
\hline
\end{tabular}

Keterangan: Angka-angka yang diikuti oleh huruf yang sama pada kolom yang sama tidak berbeda nyata setelah dilakukan uji HSD Tukey $5 \%$, (-): tidak ada interaksi.

Data yang ditampilkan oleh Tabel 1, menunjukkan panjang akar manual antar kultivar tidak berbeda nyata baik pada 5 maupun 9 mst. Kondisi kekeringan mengakibatkan penurunan panjang akar total secara nyata pada 9 mst. Kondisi kekeringan pada awal fase vegetatif mampu mengakibatkan terjadinya penurunan panjang akar primer (Ranawake et al. 2011 cit. Rosawanti, 2016). 
Tabel 2. Panjang akar total manual saat panen

\begin{tabular}{lccc}
\hline \multirow{2}{*}{ Kultivar } & \multicolumn{2}{c}{ Panjang Akar Total Manual $(\mathrm{m})$ pada Perlakuan } & \multirow{2}{*}{ Rerata } \\
\cline { 2 - 3 } & Cukup Air & Kekeringan & 43.48 \\
\hline Anjasmoro & $53.97 \mathrm{bc}$ & $32.99 \mathrm{def}$ & 58.30 \\
Burangrang & $80.38 \mathrm{a}$ & $36.21 \mathrm{def}$ & 49.33 \\
Demas 1 & $61.77 \mathrm{~b}$ & $36.89 \mathrm{def}$ & 35.76 \\
Dering 1 & $41.92 \mathrm{cde}$ & $29.60 \mathrm{ef}$ & 35.43 \\
Devon 1 & $47.13 \mathrm{bcd}$ & $23.72 \mathrm{f}$ & + \\
\hline Rerata & 57.03 & 31.88 & \\
\hline CV(\%) & & 10.12 & \\
\hline
\end{tabular}

Keterangan: Angka-angka yang diikuti oleh huruf yang sama pada kolom yang sama tidak berbeda nyata setelah dilakukan uji HSD Tukey $5 \%,(+)$ : ada interaksi.

Saat panen terdapat interaksi antara kultivar dan pengairan terhadap panjang akar manual, berdasarkan Tabel 2 kekeringan menurunkan panjang akar total manual dengan tingkat yang berbeda antar kultivar. Pada kondisi cukup air Burangrang memiliki akar terpanjang, namun menurun paling banyak pada kondisi kekeringan, sehingga sama panjang dengan Anjasmoro dan Demas 1. Devon 1 dan Dering 1 pada kondisi cukup air relatif memiliki akar paling pendek, namun pada kondisi kekeringan tidak berbeda nyata dengan kultivar yang lain. Menurut Robert (2004) dalam Jamilah (2012), tanaman dalam kondisi cekaman kekeringan mengalami pertumbuhan perakaran yang terhambat dikarenakan ketidakmampuan tanaman dalam mengatur pertumbuhannya secara sempurna. Pertumbuhan akar semakin terganggu dan tertekan seiring dengan lamanya pemberian cekaman kekeringan selama periode tumbuh tanaman (Himim 1996, Efendi 2009 cit. Sacita, 2016).

Panjang akar total yang diukur dengan area meter pada 5 mst ditunjukkan oleh Tabel 3, diketahui terdapat interaksi antara pengairan dan kultivar terhadap panjang akar. Pada kondisi cukup air Devon 1 mempunyai akar terpanjang, namun pada kondisi kekeringan mengalami penurunan paling banyak sehingga menjadi tidak berbeda nyata dengan kultivar lain. Anjasmoro, Demas 1, dan Dering 1 memiliki panjang akar yang sama pada kondisi cukup air dan merupakan paling pendek, sedangkan Burangrang tidak berbeda nyata dengan semua kultivar. 
Pratiwi et al., / Vegetalika. 2019. 8(4): 276-291

Tabel 3. Panjang akar total area meter pada 5 mst

\begin{tabular}{|c|c|c|c|}
\hline \multirow[t]{2}{*}{ Kultivar } & \multicolumn{2}{|c|}{$\begin{array}{c}\text { Panjang Akar Total Area Meter (m) pada } \\
\text { Perlakuan }\end{array}$} & \multirow[t]{2}{*}{ Rerata } \\
\hline & Cukup Air & Kekeringan & \\
\hline Anjasmoro & $5.03 \mathrm{~b}$ & $2.93 \mathrm{~b}$ & 3.98 \\
\hline Burangrang & $5.33 a b$ & $3.71 \mathrm{~b}$ & 4.52 \\
\hline Demas 1 & $4.10 \mathrm{~b}$ & $2.86 \mathrm{~b}$ & 3.48 \\
\hline Dering 1 & $4.33 \mathrm{~b}$ & $3.02 b$ & 3.68 \\
\hline Devon 1 & $8.67 \mathrm{a}$ & $2.46 \mathrm{~b}$ & 5.57 \\
\hline Rerata & 5.49 & 3.00 & + \\
\hline $\mathrm{CV}(\%)$ & & 6.63 & \\
\hline
\end{tabular}

Keterangan: Angka-angka yang diikuti oleh huruf yang sama pada kolom yang sama tidak berbeda nyata setelah dilakukan uji HSD Tukey $5 \%,(+)$ : ada interaksi.

Dari Tabel 4 diketahui pada 9 mst, Devon 1 mempunyai akar terpanjang, sedangkan Dering 1 memiliki akar paling pendek. Saat panen Demas 1 dan Burangrang mengalami peningkatan sehingga menjadi yang terpanjang meskipun tidak berbeda nyata dengan Devon 1. Kultivar Dering 1 tetap memiliki akar terpendek namun menjadi tidak berbeda dengan Anjasmoro yang panjang akarnya menurun saat panen. Pada 9 mst kekeringan menyebabkan penurunan panjang akar secara nyata, namun saat panen meskipun kekeringan juga menurunkan panjang akar pengaruhnya menjadi tidak nyata.

Tabel 4. Panjang akar total area meter pada $9 \mathrm{mst}$ dan panen

\begin{tabular}{lcc} 
& \multirow{2}{*}{ Kultivar } & \multicolumn{2}{c}{ Panjang Akar Total Area Meter $(\mathrm{m})$} \\
\cline { 2 - 3 } & $9 \mathrm{mst}$ & Panen \\
\hline Anjasmoro & $11.29 \mathrm{ab}$ & $9.47 \mathrm{~b}$ \\
Burangrang & $12.18 \mathrm{ab}$ & $14.18 \mathrm{a}$ \\
Demas 1 & $11.89 \mathrm{ab}$ & $14.39 \mathrm{a}$ \\
Dering 1 & $7.95 \mathrm{~b}$ & $9.85 \mathrm{~b}$ \\
Devon 1 & $12.79 \mathrm{a}$ & $13.08 \mathrm{ab}$ \\
\hline Cukup Air & $14.02 \mathrm{y}$ & $14.74 \mathrm{y}$ \\
Kekeringan & $8.43 \mathrm{z}$ & $9.65 \mathrm{y}$ \\
\hline Interaksi & - & - \\
\hline CV(\%) & 22.79 & 8.30 \\
\hline
\end{tabular}

Keterangan: Data pada saat panen ditransformasikan ke dalam log. Angka-angka yang diikuti oleh huruf yang sama pada kolom yang sama tidak berbeda nyata setelah dilakukan uji HSD Tukey $5 \%$, (-): tidak ada interaksi. 
Tabel 5. Luas permukaan akar manual pada 5 dan 9 mst

\begin{tabular}{lcc} 
& \multirow{2}{*}{ Kultivar } & \multicolumn{2}{c}{ Luas Permukaan Akar Manual $\left(\mathrm{dm}^{2}\right)$} \\
\cline { 2 - 3 } & $5 \mathrm{mst}$ & $9 \mathrm{mst}$ \\
\hline Anjasmoro & $4.23 \mathrm{a}$ & $9.41 \mathrm{ab}$ \\
Burangrang & $5.10 \mathrm{a}$ & $10.07 \mathrm{a}$ \\
Demas 1 & $4.80 \mathrm{a}$ & $10.57 \mathrm{a}$ \\
Dering 1 & $3.72 \mathrm{a}$ & $7.72 \mathrm{~b}$ \\
Devon 1 & $4.11 \mathrm{a}$ & $10.78 \mathrm{a}$ \\
\hline Cukup Air & $5.49 \mathrm{y}$ & $13.53 \mathrm{y}$ \\
Kekeringan & $3.29 \mathrm{z}$ & $5.89 \mathrm{z}$ \\
\hline Interaksi & - & - \\
\hline CV(\%) & 27.56 & 11.39 \\
\hline
\end{tabular}

Keterangan: Angka-angka yang diikuti oleh huruf yang sama pada kolom yang sama tidak berbeda nyata setelah dilakukan uji HSD Tukey $5 \%$, (-): tidak ada interaksi.

Data luas permukaan akar yang diukur manual pada Tabel 5 menunjukkan kondisi kekeringan berpengaruh nyata terhadap penurunan luas permukaan akar pada 5 dan 9 mst. Luas permukaan akar antar kultivar kedelai tidak berbeda secara nyata pada $5 \mathrm{mst}$, pada 9 mst kultivar Burangrang, Demas 1, dan Devon 1 mempunyai luas permukaan akar sama besar, namun tidak berbeda nyata dengan Anjasmoro yang luas permukaan akarnya lebih kecil, sedangkan Dering 1 merupakan yang terkecil di antara kultivar lain.

Tabel 6. Luas permukaan akar manual saat panen

\begin{tabular}{lccc} 
& \multirow{2}{*}{ Kultivar } & \multicolumn{2}{c}{ Luas Permukaan Akar Manual $\left(\mathrm{dm}^{2}\right)$} \\
& \multicolumn{2}{c}{ pada Perlakuan } & \multirow{2}{*}{ Rerata } \\
\cline { 2 - 3 } & \multicolumn{1}{c}{ Cukup Air } & Kekeringan & \\
\hline Anjasmoro & $12.43 \mathrm{bc}$ & $6.22 \mathrm{e}$ & 9.33 \\
Burangrang & $20.99 \mathrm{a}$ & $7.14 \mathrm{de}$ & 14.07 \\
Demas 1 & $13.74 \mathrm{~b}$ & $7.67 \mathrm{cde}$ & 10.71 \\
Dering 1 & $11.58 \mathrm{bcd}$ & $4.96 \mathrm{e}$ & 8.27 \\
Devon 1 & $12.71 \mathrm{~b}$ & $5.61 \mathrm{e}$ & 9.16 \\
\hline Rerata & 14.29 & 6.32 & + \\
\hline CV(\%) & \multicolumn{3}{c}{13.51} \\
\hline
\end{tabular}

Keterangan: Angka-angka yang diikuti oleh huruf yang sama pada kolom yang sama tidak berbeda nyata setelah dilakukan uji HSD Tukey $5 \%,(+)$ : ada interaksi.

Luas permukaan akar manual saat panen terdapat interaksi antara pengaruh kondisi air yang diberikan dan kultivar terhadap luas permukaan akar yang ditampilkan pada Tabel 6. Kekeringan menurunkan luas permukaan akar dengan tingkat yang berbeda antar kultivar. Burangrang mempunyai luas permukaan akar terbesar pada kondisi cukup air, sedangkan Anjasmoro dan Dering 1 merupakan terendah, meskipun tidak berbeda nyata dengan Demas 1 dan Devon 1. Pada kondisi kekeringan, luas permukaan akar 
Burangrang menurun paling banyak sehingga sama besar dengan Demas 1. Kultivar Devon 1 mengalami penurunan sehingga menjadi sama besar dan tidak berbeda nyata dengan Anjasmoro dan Dering 1 yang memiliki luas terendah.

Menurut Prasad et al. (2008), pembelahan dan perkembangan sel tanaman secara umum sangat dipengaruhi oleh keberadaan air baik di dalam maupun di luar sel tanaman. Kekeringan akan menghambat pembelahan dan perkembangan sel, sehingga akar tidak mampu melakukan distribusi dan perluasan dengan maksimal. Distribusi akar yang minim mempengaruhi ukuran perakaran termasuk luas permukaan akar.

Tabel 7. Luas permukaan akar area meter pada $5 \mathrm{mst}$

\begin{tabular}{|c|c|c|c|}
\hline \multirow{2}{*}{ Kultivar } & \multicolumn{2}{|c|}{$\begin{array}{l}\text { Luas Permukaan Akar Area Meter }\left(\mathrm{dm}^{2}\right) \\
\text { pada Perlakuan }\end{array}$} & \multirow[t]{2}{*}{ Rerata } \\
\hline & Cukup Air & Kekeringan & \\
\hline Anjasmoro & $1.51 \mathrm{~b}$ & $0.89 \mathrm{~b}$ & 1.20 \\
\hline Burangrang & $1.71 \mathrm{ab}$ & $1.15 b$ & 1.43 \\
\hline Demas 1 & $1.40 \mathrm{~b}$ & $1.03 \mathrm{~b}$ & 1.22 \\
\hline Dering 1 & $1.57 \mathrm{~b}$ & $0.86 \mathrm{~b}$ & 1.22 \\
\hline Devon 1 & $2.85 \mathrm{a}$ & $0.79 \mathrm{~b}$ & 1.82 \\
\hline Rerata & 1.81 & 0.94 & + \\
\hline CV(\%) & & & \\
\hline
\end{tabular}

Keterangan: Angka-angka yang diikuti oleh huruf yang sama pada kolom yang sama tidak berbeda nyata setelah dilakukan uji HSD Tukey $5 \%,(+)$ : ada interaksi.

Dari Tabel 7 diketahui luas permukaan akar yang diukur menggunakan area meter pada $5 \mathrm{mst}$, terdapat interaksi antara pengaruh pengairan dan kultivar terhadap luas permukaan akar. Kekeringan berpengaruh menurunkan luas permukaan akar masingmasing kultivar. Pada kondisi cukup air, luas permukaan akar Devon 1 merupakan yang terbesar, sedangkan Anjasmoro, Demas 1, dan Dering 1 relatif sama dan merupakan yang terendah. Kultivar Burangrang tidak berbeda nyata dengan keempat kultivar lain. Pada kondisi kekeringan Devon 1 mengalami penurunan paling banyak, meskipun antar kutlivar tidak terdapat perbedaan secara nyata.

Jumlah air yang diserap oleh akar sangat bergantung pada kandungan air tanah, kemampuan partikel tanah untuk menahan air serta kemampuan akar untuk menyerap air (Nio et al. 2010 cit. Nio dan Torey, 2013). Cekaman kekeringan mengakibatkan keterbatasan air tersedia dalam tanah, sehingga penyerapan air oleh akar tidak maksimal akibatknya kebutuhan untuk tumbuh tidak terpenuhi dan akan mempengaruhi perkembangan sistem perakaran sehingga didapatkan luas permukaan akar yang rendah. 
Tabel 8. Luas permukaan akar area meter pada 9 mst dan panen

\begin{tabular}{lcc} 
& Kultivar & Luas Permukaan Akar Area Meter $\left(\mathrm{dm}^{2}\right)$ \\
\cline { 2 - 3 } & $9 \mathrm{mst}$ & Panen \\
\hline Anjasmoro & $3.55 \mathrm{ab}$ & $2.42 \mathrm{~b}$ \\
Burangrang & $3.40 \mathrm{ab}$ & $3.52 \mathrm{a}$ \\
Demas 1 & $3.71 \mathrm{a}$ & $3.59 \mathrm{a}$ \\
Dering 1 & $2.67 \mathrm{~b}$ & $2.91 \mathrm{ab}$ \\
Devon 1 & $3.57 \mathrm{ab}$ & $2.88 \mathrm{ab}$ \\
\hline Cukup Air & $4.28 \mathrm{y}$ & $4.17 \mathrm{y}$ \\
Kekeringan & $2.48 \mathrm{z}$ & $1.95 \mathrm{z}$ \\
\hline Interaksi & - & - \\
\hline CV $(\%)$ & 16.17 & 18.24 \\
\hline
\end{tabular}

Keterangan: Data pada saat panen ditransformasikan ke dalam log. Angka-angka yang diikuti oleh huruf yang sama pada kolom yang sama tidak berbeda nyata setelah dilakukan uji HSD Tukey $5 \%$, (-): tidak ada interaksi.

Berdasarkan Tabel 8 diketahui kondisi kekeringan menyebabkan penurunan secara nyata terhadap luas permukaan akar yang diukur dengan area meter pada 9 mst dan saat panen. Pada kultivar Demas 1 mempunyai luas terbesar pada 9 mst, sedangkan Dering 1 luas permukaan akarnya terendah. Kultivar lain tidak berbeda nyata dengan kedua kultivar tersebut. Saat panen Demas 1 tetap memiliki luas permukaan akar terbesar dan menjadi sama besar dengan Burangrang. Kultivar Dering 1 mengalami peningkatan luas permukaan akar pada saat panen dan menjadi sama besar dengan Devon 1, keduanya tidak berbeda nyata dengan ketiga kultivar lain. Luas permukaan akar Anjasmoro mengalami penurunan sehingga menjadi yang terendah.

Data diameter akar yang diukur secara manual pada tanaman 5 mst ditampilkan oleh Tabel 9, menunjukkan interaksi antara pengaruh pengairan dengan kultivar terhadap diameter akar. Kondisi kekeringan mengakibatkan penurunan diameter akar antar kultivar pada tingkatan berbeda. Pada kondisi cukup air Dering 1 mempunyai diameter akar terbesar meskipun tidak berbeda secara nyata. Diameter akar kultivar Anjasmoro dan Demas 1 merupakan yang terkecil. Pada kondisi kekeringan, Dering 1 mengalami penurunan paling banyak sehingga diameternya sama besar dengan kultivar lain. Diameter akar pada Burangrang juga menurun secara nyata dan menjadi diameter terkecil. 
Tabel 9. Diameter akar manual pada $5 \mathrm{mst}$

\begin{tabular}{|c|c|c|c|}
\hline \multirow[t]{2}{*}{ Kultivar } & \multicolumn{2}{|c|}{$\begin{array}{l}\text { Diameter Akar Manual (mm) } \\
\text { pada Perlakuan }\end{array}$} & \multirow[t]{2}{*}{ Rerata } \\
\hline & Cukup Air & Kekeringan & \\
\hline Anjasmoro & $0.75 a b c$ & $0.66 \mathrm{bc}$ & 0.71 \\
\hline Burangrang & $0.91 \mathrm{ab}$ & $0.56 \mathrm{c}$ & 0.74 \\
\hline Demas 1 & $0.75 a b c$ & $0.59 \mathrm{bc}$ & 0.67 \\
\hline Dering 1 & $0.99 a$ & $0.60 \mathrm{bc}$ & 0.80 \\
\hline Devon 1 & $0.90 \mathrm{ab}$ & $0.63 \mathrm{bc}$ & 0.77 \\
\hline Rerata & 0.86 & 0.61 & + \\
\hline $\mathrm{CV}(\%)$ & & 10.63 & \\
\hline
\end{tabular}

Keterangan: Angka-angka yang diikuti oleh huruf yang sama pada kolom yang sama tidak berbeda nyata setelah dilakukan uji HSD Tukey $5 \%,(+)$ : ada interaksi.

Tabel 10 menunjukkan bahwa diameter akar yang diukur manual pada 9 mst dan panen, seiring bertambahnya umur tanaman diameter akar mengalami penurunan. Diameter akar antar kultivar yang diuji tidak berbeda secara nyata baik pada 9 mst maupun saat panen, namun terlihat kekeringan menurunkan diameter akar pada 9 mst dan panen.

Tabel 10. Diameter akar manual pada 9 mst dan panen

\begin{tabular}{lcc} 
& \multirow{2}{*}{ Kultivar } & \multicolumn{2}{c}{ Diameter Akar Manual $(\mathrm{mm})$} \\
\cline { 2 - 3 } & $9 \mathrm{mst}$ & Panen \\
\hline Anjasmoro & $0.75 \mathrm{a}$ & $0.68 \mathrm{a}$ \\
Burangrang & $0.75 \mathrm{a}$ & $0.73 \mathrm{a}$ \\
Demas 1 & $0.86 \mathrm{a}$ & $0.69 \mathrm{a}$ \\
Dering 1 & $0.79 \mathrm{a}$ & $0.78 \mathrm{a}$ \\
Devon 1 & $0.86 \mathrm{a}$ & $0.73 \mathrm{a}$ \\
\hline Cukup Air & $0.96 \mathrm{y}$ & $0.81 \mathrm{y}$ \\
Kekeringan & $0.65 \mathrm{z}$ & $0.64 \mathrm{z}$ \\
\hline Interaksi & - & - \\
\hline CV(\%) & 11.32 & 10.98 \\
\hline Ke
\end{tabular}

Keterangan: Angka-angka yang diikuti oleh huruf yang sama pada kolom yang sama tidak berbeda nyata setelah dilakukan uji HSD Tukey $5 \%$, (-): tidak ada interaksi.

Akar tanaman kedelai mengalami pengurangan ukuran diameter stele dan xilem sebagai mekanisme toleransi tanaman dalam menghadapi cekaman kekeringan (Makbul et al., 2011 cit. Rosawanti, et al. 2015). Diameter yang kecil memiliki saluran akar lebih sempit, sehingga dapat membuat daya kapilaritas akar semakin tinggi (Christy et al. 2015 cit. Tirta et al. 2017). Daya kapilaritas berpengaruh terhadap daya serap oleh akar. Apabila daya kapilaritas yang dimiliki akar semakin tinggi akan membuat daya serap akar terhadap hara dan air pada larutan tanah menjadi semakin efektif. 
Tabel 11. Diameter akar area meter pada umur 5, 9 mst dan panen

\begin{tabular}{lccc} 
& \multirow{2}{*}{ Kultivar } & \multicolumn{3}{c}{ Diameter Akar Area Meter $(\mathrm{mm})$} \\
\cline { 2 - 4 } & $5 \mathrm{mst}$ & $9 \mathrm{mst}$ & Panen \\
\hline Anjasmoro & $0.97 \mathrm{a}$ & $1.00 \mathrm{ab}$ & $0.89 \mathrm{a}$ \\
Burangrang & $0.98 \mathrm{a}$ & $0.90 \mathrm{~b}$ & $0.86 \mathrm{a}$ \\
Demas 1 & $1.12 \mathrm{a}$ & $1.02 \mathrm{ab}$ & $0.86 \mathrm{a}$ \\
Dering 1 & $1.06 \mathrm{a}$ & $1.12 \mathrm{a}$ & $0.95 \mathrm{a}$ \\
Devon 1 & $1.05 \mathrm{a}$ & $0.88 \mathrm{~b}$ & $0.79 \mathrm{a}$ \\
\hline Cukup Air & $1.06 \mathrm{y}$ & $1.00 \mathrm{y}$ & $0.91 \mathrm{y}$ \\
Kekeringan & $1.01 \mathrm{y}$ & $0.97 \mathrm{y}$ & $0.82 \mathrm{y}$ \\
\hline Interaksi & - & - & - \\
\hline CV(\%) & 17.37 & 10.49 & 16.23 \\
\hline
\end{tabular}

Keterangan: Angka-angka yang diikuti oleh huruf yang sama pada kolom yang sama tidak berbeda nyata setelah dilakukan uji HSD Tukey $5 \%$, (-): tidak ada interaksi.

Data diameter akar yang diukur dengan area meter yang ditampilkan oleh Tabel 11 menunjukkan pada 5 mst tidak terdapat perbedaan diameter akar antar kultivar yang diuji. Pada 9 mst, kultivar Burangrang dan Devon 1 mengalami penurunan dan menjadi yang terkecil. Pada 9 mst, Dering 1 memiliki diameter akar yang tetap, namun merupakan yang terbesar. Kultivar Anjasmoro dan Demas 1 berada di antaranya dan tidak berbeda nyata dengan ketiga kultivar tersebut. Diameter akar menurun pada saat panen dan antar kultivar menjadi tidak berbeda nyata. Cekaman kekeringan tidak berpengaruh secara nyata terhadap diameter akar pada 5 dan 9 mst, serta panen, namun pada kondisi kekeringan diameter akar relatif lebih kecil dibandingkan diameter akar pada kondisi cukup air.

Tabel 12. Volume akar manual pada 5 dan 9 mst

\begin{tabular}{lcc}
\hline & \multirow{2}{c}{ Kultivar } & \multicolumn{2}{c}{ Volume $(\mathrm{ml})$} \\
\cline { 2 - 3 } & $5 \mathrm{mst}$ & $9 \mathrm{mst}$ \\
\hline Anjasmoro & $7.67 \mathrm{a}$ & $19.00 \mathrm{ab}$ \\
Burangrang & $10.00 \mathrm{a}$ & $20.92 \mathrm{ab}$ \\
Demas 1 & $8.25 \mathrm{a}$ & $24.25 \mathrm{a}$ \\
Dering 1 & $7.83 \mathrm{a}$ & $16.92 \mathrm{~b}$ \\
Devon 1 & $8.42 \mathrm{a}$ & $25.25 \mathrm{a}$ \\
\hline Cukup Air & $11.77 \mathrm{y}$ & $32.60 \mathrm{y}$ \\
Kekeringan & $5.10 \mathrm{z}$ & $9.93 \mathrm{z}$ \\
\hline Interaksi & $(-)$ & $(-)$ \\
\hline CV(\%) & 29.66 & 18.43 \\
\hline
\end{tabular}

Keterangan: Angka-angka yang diikuti oleh huruf yang samapada kolom yang sama tidak berbeda nyata setelah dilakukan uji HSD Tukey $5 \%$, (-): tidak ada interaksi. 
Dari Tabel 12 diketahui setelah 9 mst, volume akar tiap kultivar mengalami peningkatan yang berbeda-beda. Kultivar Demas 1 dan Devon 1 memiliki akar dengan volume yang sama dan terbesar. Kultivar Dering 1 mengalami peningkatan dibandingkan saat $5 \mathrm{mst}$, namun menjadi volume yang terendah. Kultivar Anjasmoro dan Burangrang memiliki volume akar yang sama dan tidak berbeda nyata dengan ketiga kultivar lain. Kekeringan menyebabkan penurunan volume akar secara nyata pada pada 5 mst dan 9 mst.

Tabel 13. Volume akar manual pada saat panen

\begin{tabular}{|c|c|c|c|}
\hline \multirow{3}{*}{ Kultivar } & \multirow{2}{*}{\multicolumn{2}{|c|}{$\begin{array}{l}\text { Volume Akar (ml) } \\
\text { pada Perlakuan }\end{array}$}} & \multirow{3}{*}{ Rerata } \\
\hline & & & \\
\hline & Cukup Air & Kekeringan & \\
\hline Anjasmoro & $23.33 \mathrm{bcd}$ & $9.42 \mathrm{de}$ & 16.38 \\
\hline Burangrang & $44.17 \mathrm{a}$ & $11.33 \mathrm{cde}$ & 27.75 \\
\hline Demas 1 & 24.58 bc & 13.33 cde & 18.96 \\
\hline Dering 1 & $25.50 \mathrm{bc}$ & 8.50 e & 17.00 \\
\hline Devon 1 & $27.67 \mathrm{~b}$ & $8.50 \mathrm{e}$ & 18.09 \\
\hline Rerata & 29.05 & 10.22 & $(+)$ \\
\hline $\mathrm{CV}(\%)$ & & 23.80 & \\
\hline
\end{tabular}

Keterangan: Angka-angka yang diikuti oleh huruf yang samapada kolom yang sama tidak berbeda nyata setelah dilakukan uji HSD Tukey $5 \%,(+)$ : ada interaksi.

Saat panen terdapat interaksi antara pengaruh pengairan dan kultivar terhadap volume akar yang ditampilkan pada Tabel 13. Kekeringan menurunkan volume akar dengan tingkat berbeda antar kultivar. Pada kondisi cukup air Burangrang memiliki volume akar terbesar, namun menurun paling banyak pada kondisi kekeringan sehingga menjadi sama besar dengan Demas 1. Keempat kultivar lain mempunyai volume akar yang tidak berbeda nyata pada kondisi cukup air. Kultivar Devon 1 pada kondisi kekeringan memiliki volume akar yang terendah dan sama dengan Dering 1 , meskipun tidak berbeda nyata dengan kultivar lain. Cekaman kekeringan dengan intensitas cukup lama akan menghambat sistem perakaran, meskipun tanaman diairi kembali, sel-sel yang rusak menyebabkan akar tidak mampu menyerap air secara optimal sehingga kemampuan akar untuk memperbanyak organ juga terhambat dan berpengaruh terhadap besar kecilnya volume akar. 
Tabel 14. Volume akar area meter pada 5 dan 9 mst serta panen

\begin{tabular}{|c|c|c|c|c|}
\hline \multirow{2}{*}{\multicolumn{2}{|c|}{ Kultivar }} & \multicolumn{3}{|c|}{ Volume Akar (ml) } \\
\hline & & $5 \mathrm{mst}$ & $9 \mathrm{mst}$ & Panen \\
\hline Anjasmoro & & $2.93 \mathrm{a}$ & $8.93 \mathrm{a}$ & $5.58 \mathrm{a}$ \\
\hline Burangrang & & $3.53 \mathrm{a}$ & $7.80 \mathrm{a}$ & $8.04 \mathrm{a}$ \\
\hline Demas 1 & & $3.36 \mathrm{a}$ & $9.84 \mathrm{a}$ & $8.40 \mathrm{a}$ \\
\hline Dering 1 & & $3.30 \mathrm{a}$ & $7.65 a$ & $7.19 a$ \\
\hline Devon 1 & & $4.73 a$ & $7.88 \mathrm{a}$ & $6.08 \mathrm{a}$ \\
\hline Cukup air & & $4.70 \mathrm{y}$ & $10.79 y$ & $9.67 y$ \\
\hline Kekeringan & & $2.44 \mathrm{y}$ & $6.06 z$ & $4.45 \mathrm{z}$ \\
\hline Interaksi & & $(-)$ & $(-)$ & $(-)$ \\
\hline $\mathrm{CV}(\%)$ & & 17.06 & 19.18 & 16.08 \\
\hline Keterangan: & $\begin{array}{l}\text { Data pada } 5 \mathrm{~ms} \\
\text { angka yang diiku } \\
\text { setelah dilakukar }\end{array}$ & $\begin{array}{l}\text { asikan k } \\
\text { ada kolc } \\
\text { idak ada }\end{array}$ & $\begin{array}{l}\text { square } \\
\text { s sama tic } \\
\text { si. }\end{array}$ & $\begin{array}{l}\text { grt). Ang } \\
\text { beda ny }\end{array}$ \\
\hline
\end{tabular}

Tabel 14 menyajikan data volume akar yang diukur dengan area meter pada tanaman 5 dan $9 \mathrm{mst}$, serta panen. Pada $5 \mathrm{mst}$ hingga panen data volume akar tidak berbeda nyata antar kultivar. Kekeringan mengakibatkan penurunan volume akar pada 9 mst dan panen. Cekaman kekeringan membatasi pertumbuhan dan perkembangan akar, ditambah penggunaan media tanam yang terbatas akan mempengaruhi ruang adaptasi akar sehingga penyebaran akar untuk meningkatkan penyerapan air dan hara terbatas. Sistem perakaran yang terbatas dalam keranjang dan lebih cepat mengalami kekurangan air mengakibatkan akar tidak mampu meningkatkan penyerapan air, sehingga volume akar menurun seiring dengan persebaran akar yang terbatas.

Berdasarkan data yang telah dipaparkan diketahui bahwa panjang akar total yang diukur secara manual memberikan akar yang lebih panjang dibandingkan jika diukur melalui area meter yang memberikan panjang jauh lebih pendek, Data luas permukaan akar yang dihitung secara manual juga menunjukkan luas yang lebih besar, begitu juga dengan volume akar yang diukur secara manual memberikan data yang lebih besar dibandingkan data yang dihitung dengan area meter. Pada data diameter akar diketahui bahwa diameter akar yang diukur dengan area meter cenderung lebih besar dibandingkan dengan diameter akar yang diukur secara manual. 
Tabel 15. Korelasi antar sifat perakaran yang diukur dengan metode manual dan area meter.

\begin{tabular}{lllll}
\hline $\begin{array}{l}\text { Manual/ } \\
\text { Areameter }\end{array}$ & $\begin{array}{l}\text { Volume Akar } \\
\text { Manual }\end{array}$ & $\begin{array}{l}\text { Panjang Akar } \\
\text { Manual }\end{array}$ & $\begin{array}{l}\text { Luas Permukaan } \\
\text { Akar Manual }\end{array}$ & $\begin{array}{l}\text { Diameter Akar } \\
\text { Manual }\end{array}$ \\
\hline $\begin{array}{l}\text { Volume Akar } \\
\text { Areameter }\end{array}$ & 0.45 & & & \\
$\begin{array}{l}\text { Panjang Akar } \\
\text { Areameter }\end{array}$ & $0.64^{* *}$ & 0.45 & & \\
$\begin{array}{l}\text { Luas Permukaan } \\
\text { Akar Areameter }\end{array}$ & $0.71^{* *}$ & $0.69^{* *}$ & $0.76^{* *}$ & \\
$\begin{array}{l}\text { Diameter Akar } \\
\text { Areameter }\end{array}$ & -0.21 & 0.02 & -0.11 & -0.31 \\
\hline
\end{tabular}
Keterangan: ${ }^{* * *}$ menunjukkan hubungan yang signifikan.

Uji korelasi dilakukan untuk mengetahui seberapa erat hasil yang diperoleh pada pengukuran perakaran dengan manual dan area meter. Menurut hasil korelasi pada Tabel 15, panjang akar dan volume akar yang diamati secara manual tidak menunjukkan adanya hubungan yang erat dengan pengukuran secara area meter. Hal ini menunjukkan pengukuran panjang akar dan volume akar secara manual dan area meter dapat memberikan nilai hasil pengukuran yang berbeda. Pada pengukuran diameter akar secara manual justru memberikan hubungan yang negatif terhadap diameter akar area meter. Pengukuran luas permukaan akar secara manual memiliki hubungan sangat erat dengan luas permukaan akar area meter, hal ini menunjukkan bahwa baik secara manual maupun dengan area meter saling memberikan nilai hasil luas permukaan akar yang tidak berbeda dan sama-sama akurat.

\section{KESIMPULAN}

1. Pada metode penelitian ini sifat perakaran pada tanaman yang mengalami kekeringan cenderung mengalami penurunan dibandingkan perakaran pada tanaman dalam kondisi cukup air.

2. Pengukuran perakaran kedelai secara manual dan area meter dapat digunakan tetapi menunjukkan hasil yang berbeda pada parameter panjang akar total, volume akar, dan diameter akar, tetapi memberikan hasil yang sama akuratnya pada luas permukaan akar. Jika dilihat dari besarnya hasil pengukuran manual memiliki tingkat 
akurasi lebih tinggi sehingga hasil lebih besar, sedangkan dengan areameter tingkat akurasi rendah.

\section{DAFTAR PUSTAKA}

Gewin. 2010. An underground revolution. Nature (466): 552-553.

Jamilah, N. 2012. Pengujian karakter morfologi untuk evaluasi ketahanan kekeringan beberapa varietas kedelai (Glycine Max (L.) Merril). Skripsi. Jurusan Biologi, Fakultas Sains Dan Teknologi, Universitas Islam Negeri (UIN) Maulana Malik Ibrahim, Malang.

Manavalan, L.P., S.K. Guttikonda, L.S. Phantran and H.T. Nguyen. 2009. Physiological and Molecular Approaches to Improve Drought Resistance in Soybean. National Center for Soybean Biotechnology and Division of Plant Sciences, University of Missouri, Columbia, Missouri. USA.

Nio, S.A. dan P. Torey. 2013. Karakter morfologi akar sebagai indikator kekurangan air pada tanaman. Jurnal Bioslogos 3 (1): 31-39.

Prasad, P.V.V., S.A. Staggenborg, Z. Ristic. 2008. Impacts of drought and/or heat Stress on physiological, developmental, growth, and yield processes of crop plants. Response of crops to limited water: Understanding and modeling water stress effects on plant growth processes Advance in Agricultural Systems Modeling Series 1 (11): 301-355.

Rosawanti, P. 2016. Pertumbuhan akar kedelai pada cekaman kekeringan. Jurnal Daun 3 (1): 21-28.

Rosawanti, P., M. Ghulamahdi, dan N. Khumaida. 2015. Respon Anatomi dan Fisiologi Akar Kedelai terhadap Cekaman Kekeringan. J. Agron. Indonesia 43 (3) : 186 192.

Sacita, A.S. 2016. Respon tanaman kedelai (Glycine max L.) terhadap cekaman kekeringan pada fase vegetatif dan generatif. Tesis. Program Studi Klimatologi Terapan. Sekolah Pascasarjana, Institut Pertanian Bogor, Bogor.

Tirta, F.A., D. Indradewa, dan E. Ambarwati. 2017. Pertumbuhan dan hasil sembilan kultivar kedelai (Glycine max (L.) Merrill) yang ditanam bersamaan dengan jagung (Zea mays L.) dalam satu lubang tanam. Vegetalika 6(1): 22-34.

Yoshida, S. 1981. Fundamental of Rice Crop Science. Philippines. The International Rice Research and Institute. 